\title{
Validity and reliability of the Polish version of the Academic Motivation Scale: a measure of intrinsic and extrinsic motivation and amotivation
}

\begin{abstract}
BACKGROUND
The Academic Motivation Scale (AMS) is a measure of motivation in education. The AMS is based on the selfdetermination theory, which subdivides motivation into amotivation, extrinsic motivation and intrinsic motivation. The main purpose of this study was to examine the validity and reliability of the Polish version of the AMS and to identify motivation to study of Polish university students.

PARTICIPANTS AND PROCEDURE

The first sample consisted of 1592 Polish university students (653 males, 939 females) majoring in physical education, physiotherapy, tourism and recreation, sport or sport and tourism management. The second sample consisted of 49 Polish university students ( 13 males, 36 females) of tourism and recreation. The AMS was validated using exploratory and confirmatory factor analysis. Cronbach's $\alpha$ was used to estimate reliability and internal consistency of the scale.
\end{abstract}

\section{RESULTS}

The AMS showed adequate levels of internal consistency (Cronbach $\alpha$ values above .78) and temporal stability (mean test-retest correlation $=.88$ ). Additionally, the fit indices of CFA were satisfactory $\left(\chi^{2} / d f=4.95, \mathrm{GFI}=.927, \mathrm{AGFI}=.910\right.$, RMSEA $=.050$ ). Female students scored higher than males on four motivation subscales and lower on amotivation.

\section{CONCLUSIONS}

The results confirmed the original seven-factor and 28-item structure of the Polish version of the AMS. The results support the use of the Polish version of the AMS as a tool for assessing university students' motivation.

\section{KEY WORDS}

sport; factor analysis; physical education; AMS; validation

Organization - The Jerzy Kukuczka Academy of Physical Education in Katowice, Poland AUthors' Contributions - A: Study design - B: Data collection - C: Statistical analysis - D: Data interpretation .

E: Manuscript preparation · F: Literature search · G: Funds collection

CORRESPonding AUthor - Magdalena Ardeńska, Academy of Physical Education in Katowice, 72 A Mikołowska Str., 40-065 Katowice, Poland, e-mail: m.ardenska@gmail.com 


\section{BACKGROUND}

Motivation is the lifeblood of human activity. Identification and analysis of the causes of human behaviour is the foundation of motivation theory, which describes these causes in the simplest possible way. Analysis of motivation should be based on a specific theory. One of the current and dynamically developing theories is the self-determination theory (SDT) by Edward Deci and Richard Ryan, which has its origin in the research on intrinsic motivation (e.g. Deci, 1971, 1972, 1975; Deci \& Ryan, 1985, 1990, 2000, 2008; Deci, Vallerand, Pelletier, \& Ryan, 1991; Ryan \& Deci, 2000a, 2000b; Ryan, Soenens, Vansteenkiste, \& Deci, 2019). The self-determination theory proposes the concept of three basic psychological needs which are innate and universal in human life: the needs for competence, relatedness and autonomy (Deci \& Ryan, 1985; Deci et al., 1991; Vallerand, 2000). The concept of basic psychological needs allows one to analyse the context and conditions needed to strengthen the development, motivation and performance of an individual (Deci et al., 1991). The fulfilment of those needs enhances well-being and motivation, as well as persistence, creativity and efficiency. Whether the social environment supports or hinders basic need satisfactions has an immense impact on people's well-being. Various types of psychopathology, anxiety, alienation and depression can be interpreted as an effect of ignoring and neglecting those basic needs (Deci \& Ryan, 1985; Ryan \& Deci, 2000a, 2000b). Basic psychological needs are of great importance for motivation in education, both for students and teachers, as well as for administrators and politicians who reform educational structures (Ardeńska et al., 2016).

According to the SDT, there are three main types of motivation which are tied to every human activity: amotivation, extrinsic motivation and intrinsic motivation (Deci \& Ryan, 1985). Motivation could form a continuum from amotivation through controlled extrinsic motivation, to autonomic intrinsic motivation due to the transformation in the process of internalisation (introjection and integration). Introjection refers to the internalisation in which an individual assumes a value without identifying with it and integration occurs when the person identifies with the value of an activity and fully accepts it (Deci, Eghrari, Patrick, \& Leone, 1994). Amotivation (AM) is the lack of willingness to act. It occurs in a situation when an individual finds no value in the activity or does not see the connection between his actions and the results. An amotivated individual might not experience a sense of competence, because they lack either the skill or the knowledge needed to carry out the activity (Ryan, 1995; Ryan \& Deci, 2000a; Ryan, Williams, Patrick, \& Deci, 2009). Extrinsic motivation (EM) embodies every activity done in order to achieve one's goals. It can be subdivided into three catego- ries: external regulation (reward and punishment), introjected regulation and identified regulation. External regulation comprises activities performed to fulfil the external demand or to gain a reward, both material (e.g. money) and non-material (e.g. praise). Introjected regulation represents a type of internal regulation that is controlling as well, as it refers to performing tasks out of pressure, to avoid the feeling of guilt and anxiety or to feel proud. Identification is the most self-determined type of extrinsic motivation. It is regulation through internalization (identification, integration). In this example, an individual has identified with the personal value of the behaviour and accepted its regulation as their own. On the other hand, intrinsic motivation describes an activity performed for its sole pleasure, without the need to achieve a specific result. People intrinsically motivated perform the activity for pure fun or challenge, not because of external pressure or for rewards (Ryan \& Deci, 2000a). Therefore, even when rewards are offered for good performance, they still have a negative effect on intrinsic motivation (Deci, Koestner, \& Ryan, 1999).

Vallerand et al. (1992) created the Academic Motivation Scale, a measure of motivation in education. It has been widely used by researchers in many countries and in various educational contexts (e.g. Cokley, Bernard, Cunningham, \& Motoike, 2001; Fairchild, Horst, Finney, \& Barron, 2005; Barkoukis, Tsorbatzoudis, Grouios, \& Sideridis, 2008; Alivernini \& Lucidi, 2008; Faye \& Sharpe, 2008; Komarraju, Karau, \& Schmeck, 2009; Horyna \& Bonds-Raacke, 2012; Karagüven, 2012; Stover, de la Iglesia, Boubeta, \& Liporace, 2012; Wilkesmann, Fischer, \& Virgillito, 2012; Guay, Ratelle, Larose, Vallerand, \& Vitoro, 2013; Maican \& Lixandroiu 2015; Orsini et al., 2015; Tóth-Király et al., 2017; Litalien et al., 2017). The AMS is based on seven-factor structure: amotivation, three types of extrinsic motivation and three types of intrinsic motivation. Extrinsic motivation is divided into external regulation (related to rewards and punishments), external introjected motivation (accepted in the processes of internalization by introjection) and external identified motivation (an acceptance following internalization by identification, considered as his or her own by the individual; the closest to intrinsic motivation). Intrinsic motivation, as described above, pertains to practising an activity for itself, just for pleasure and satisfaction (Deci, 1975; Deci \& Ryan, 1985; Vallerand et al., 1992). A behaviour correlated with interest, enjoyment and perceived feeling of choice reflects this autonomous type of motivation (Ryan, Koestner, \& Deci, 1991). The taxonomy of intrinsic motivation was suggested by Vallerand, Blais, Brière, and Pelletier (1989) and Vallerand et al. (1992), who recognized that the previous descriptions of internal motivation revealed its complex structure and
Validity and reliability of the Polish version of the Academic Motivation Scale 
Magdalena Ardeńska, Agnieszka Ardeńska, Rajmund Tomik indicated the presence of three types of this motivation. Therefore, intrinsic motivation was subdivided into three categories: motivation to know, motivation toward accomplishments, motivation to experience stimulation. Motivation to know is described as engagement in an activity performed for pleasure and satisfaction, which are derived from learning, exploration and the process of trying to understand a new concept. Intrinsic motivation to know refers to exploration, curiosity, intellectual pursuit, motivation to learn, the search for meaning, epistemic need for knowledge and understanding. Motivation toward accomplishments is about performing an activity for pleasure and satisfaction that stems from an attempt to accomplish something or to create something. Motivation to accomplish occurs when an individual focuses more on the achievement process than on the results. Motivation to experience stimulation is described as engagement in the activity for stimulating experiences (e.g. sensory pleasure, fun and excitement) which are derived from that activity (Vallerand et al., 1992). The holistic feeling of flow (Csikszentmihalyi, 1990), feelings of excitement and aesthetic stimulating experiences indicate the presence of this subtype of intrinsic motivation (Vallerand et al., 1992). Although the intrinsic motivation is the most important form of motivation, most activities performed by people are not intrinsically motivated. The freedom to be intrinsically motivated is significantly impaired in early childhood because of social roles and other social demands; thus individuals have to assume responsibility for external demands (Ryan \& Deci, 2000a).

In the Vallerand (2000) study, the hierarchical model of motivation was proposed. The hierarchical model describes two horizontal impact processes, where the motivation of one level influences the motivation of another level in the hierarchy (Vallerand \& Lalande, 2011). Vallerand, Pelletier \& Koestner (2008) emphasized that motivational research is still dynamic, and the self-determination theory allows for a better understanding of processes related to human activity in the areas of education, work, recreation, parental responsibilities, sport and health.

Along with the development of the theories of motivation, a statistical tool was created, which allows systematization of different, sometimes very complex sets of needs. This tool was a factor analysis (Cattell, 1971; Eysenck, 1991, 1992; Costa \& McCrae, 1992), which allows reduction of the number of factors to the desired minimum. Exploratory factor analysis (EFA) is performed to explore the possible underlying factor structure of a set of observed variables. Confirmatory factor analysis (CFA) is used to test the hypothesis that a relationship between the observed variables and their underlying latent construct exists (Suhr, 2006)

\section{PARTICIPANTS AND PROCEDURE}

\section{PARTICIPANTS}

Sample 1 comprised 1592 Polish university students, 653 males aged 19-34 $(M=21.56, S D=2.17)$ and 939 females aged $18-33(M=21.52, S D=1.90)$. Their overall mean age was 21.54 years $(S D=2.02)$, ranging from 18 to 34 . Students were enrolled in either the physical education, physiotherapy, tourism and recreation, sport or tourism management degree programme at universities in southern and western Poland. Sample 2 comprised 49 university students of tourism and recreation, 13 males and 36 females.

\section{MEASURE AND PROCEDURE}

The Academic Motivation Scale (AMS) was used (Vallerand et al., 1992). This tool is accessible for research purposes on the Research Laboratory on Social Behavior (RLSB) website. The AMS was translated from English to Polish with the back-translation procedure. The Polish version of the AMS, similarly to the original, consists of 28 items assigned to seven subscales (four items per each subscale) described in the self-determination theory: amotivation, extrinsic motivation (external regulation, introjected regulation, identified regulation), and intrinsic motivation (to know, to accomplish and to experience stimulation). All items were assessed on a 7-point Likert scale (1 - strongly disagree, 2 - disagree, 3 - slightly disagree, 4 - don't know, 5 - slightly agree, 6 - agree, 7 - strongly agree). The survey was conducted in the years 2013-2018 by the use of paper-and-pencil questionnaires as well as web-based questionnaires. Participants were informed that the survey is anonymous and voluntary. After being translated, the AMS was subjected to a validation procedure. Validation of the research tool, i.e. the evaluation of the theoretical validity of the questionnaire after translation into Polish, was performed in several stages, using exploratory factor analysis and confirmatory factor analysis. Validation is one of the stages of cultural adaptation of the research tool after its translation (Hornowska \& Paluchowski, 2011). In order to assess the temporal stability, a test-retest technique was used. According to Hornowska (2018), while determining the time period between pretest and retest, two contradictory conditions should be taken into consideration. First, the time period should be long enough for the respondents to forget their answers. Second, the time period should be short enough to avoid the change of respondents' subjective assessments measured by the scale, for e.g. resulting from the learning process. There is even a specific variant of the test-retest statistical technique, with no time period between the tests. In the present study, the 
Table 1

EFA for the 7-factor AMS $(N=1592)$

\begin{tabular}{lcccc}
\hline Factor & Eigenvalue & \% of variance & $\begin{array}{c}\text { Cumulative } \\
\text { eigenvalue }\end{array}$ & $\begin{array}{c}\text { Cumulative } \\
\text { \% of variance }\end{array}$ \\
\hline 1 & 9.98 & 35.65 & 9.98 & 35.65 \\
2 & 2.64 & 9.45 & 12.63 & 45.10 \\
3 & 2.48 & 8.85 & 15.10 & 53.94 \\
4 & 1.38 & 4.92 & 16.48 & 58.86 \\
5 & 0.95 & 3.39 & 17.43 & 62.25 \\
7 & 0.89 & 3.16 & 18.31 & 65.41 \\
\hline
\end{tabular}

Validity and reliability of the Polish version of the Academic Motivation Scale chosen time period was quite short but the pretest and retest were divided by lectures and the stressful experiences of taking an exam.

\section{DATA ANALYSIS}

All statistical analyses were performed with the STATISTICA package (version 13.1). First, the factor analyses were done, such as an exploratory factor analysis (EFA) in the multidimensional analyses module and a confirmatory factor analysis (CFA) in the structural equation modelling module. EFA was used to study the AMS structure through the Kaiser criterion and Cattell's scree plot (Cattell, 1966). CFA was performed to evaluate the goodness of fit of the assumed five models using the generalized least squares (GLS) technique, and to evaluate the factor loadings of the best fitting model. Cronbach's $\alpha$ statistics were used to estimate the reliability of the Polish version of the AMS. In order to assess the temporal stability of the AMS, a second sample comprising 49 university students completed the AMS twice, before and after the lectures and stressful exams. Likert data were collected from 28 items divided into seven subscales (four items per subscale), and descriptive statistics such as means and standard deviations were calculated to examine motivation of university students from sample 1 (Likert, 1932; Boone \& Boone, 2012). In order to compare male and female students' motivation in each of the seven subscales, the one-way ANOVA was applied. The assumed significance level was set at $\alpha<.05$.

\section{RESULTS}

First, an exploratory factor analysis for 28 variables (28 questionnaire items) was performed. Due to the Kaiser criterion, the eigenvalues for the correlation matrix were computed (Table 1). The eigenvalues

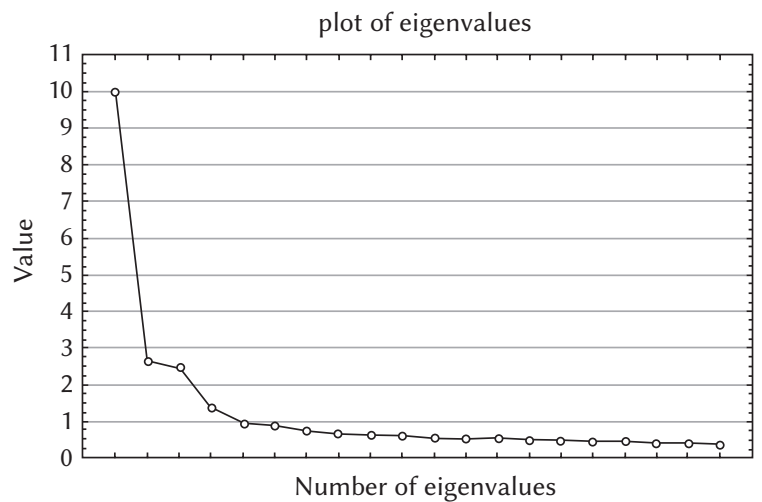

Figure 1. Cattell's scree plot.

of four factors were greater than 1.00 and they explained $58.86 \%$ of the total variance. Seven factors explained $68.04 \%$ of the total variance, but the eigenvalues for the fifth, sixth and seventh factor were below 1.00. The last substantial drop in the magnitude of eigenvalues was determined from the fourth factor, through examination of Cattell's scree plot (Figure 1).

Next, the data was subjected to confirmatory factor analysis (CFA). The generalized least squares (GLS) method was used. Because exploratory factor analysis did not confirm the seven-factor structure of the AMS, five models were tested and compared (Table 2). In Model 1 and Model 5, seven factors were postulated, which corresponded to the seven subscales: amotivation, extrinsic motivation (external regulation, introjected regulation, identified regulation), and intrinsic motivation (IM-to know, IM-accomplishment and IM-stimulation). In Model 1 seven uncorrelated factors were postulated. In Model 2 three factors were postulated; these factors corresponded to the three types of motivation: amotivation, extrinsic motivation and intrinsic motivation. In Model 3 four factors were postulated because of 
Table 2

Fit statistics of the CFA for the alternative AMS models $(N=1592)$

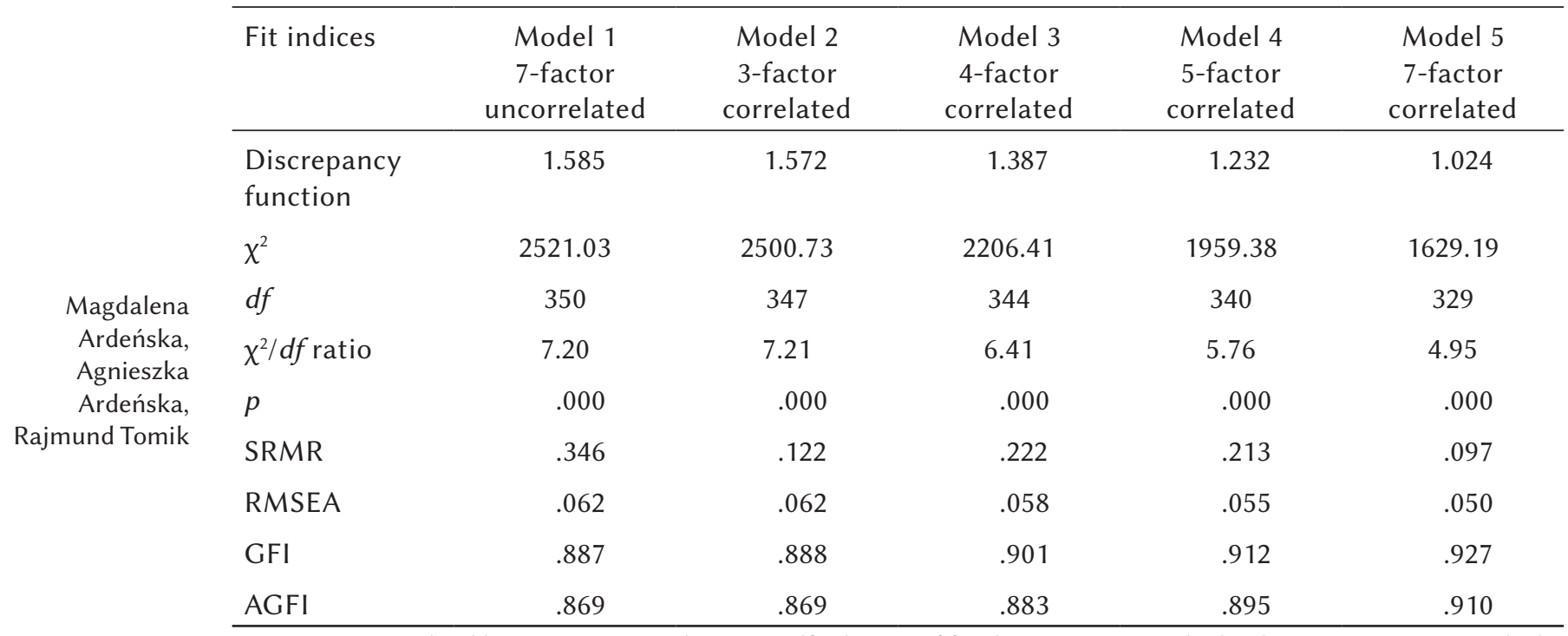

Note. GLS - generalized least squares; $\chi^{2}$ - chi square; $d f$ - degrees of freedom; SRMR - standardized root mean-square residual; RMSEA - root mean square error of approximation

the results of EFA (eigenvalues of four factors greater than one and the analysis of Cattell's scree plot). In Model 4 five factors were postulated; these factors corresponded to amotivation, external regulation, introjected regulation, identified regulation and intrinsic motivation. In Model 5 seven correlated factors were postulated. None of the models reached statistical non-significance $\left(\chi^{2} p<.01\right)$, but considering that the $\chi^{2}$ value is strongly adversely influenced by large samples due to excessive power, the alternative fit indices should be examined (Sagan, 2003a, 2003b; Barkoukis et al., 2008). The 7-factor correlated Model 5 reached acceptable fit levels. First, root mean squared error of approximation (RMSEA) was .05. Second, standardised root mean square residual (SRMR) and the discrepancy function were the smallest of the other models. Finally, the goodness of fit index (GFI) and adjusted goodness of fit index (AGFI) values were satisfactory, over .90. Loadings from the 7-factor correlated Model 5 are displayed in Table 3. The covariance between latent variables is presented in Table 4. All factor loadings and all covariances were statistically significant $(p<.001)$. The 7 -factor correlated Model 5 yielded satisfactory fit values and fits the data reasonably well.

The internal consistency of the seven-factor structure of the AMS was measured using Cronbach's $\alpha$, which indicated that the subscales demonstrate adequate internal consistency (Table 5). Cronbach $\alpha$ values were above .78 in all cases. Alpha values for the whole AMS $(\alpha=.87)$ are presented in the first column of Table 5. Alpha values after removing the items were lower than .87 for all items of motivation sub- scales. Alpha values were higher after removing all items of amotivation. Cronbach $\alpha$ coefficients, which were computed separately for the amotivation scale (4 items) and motivation scale (24 items), are shown in the second column of Table 5. Alpha values after removing the items of amotivation were lower than .86 in all cases. Alpha values for items of the motivation subscale were lower than .93 , except for the item external regulation 1, which was .93. Alpha for each of the seven subscales of the AMS are presented in the third column. All alpha values after removing the items (the fourth column) were lower than alpha for all seven subscales.

In order to test the temporal stability of an instrument, the Polish version of the AMS was completed twice by 49 university students, before and after lectures and exams. The test-retest coefficients were higher than .70 for all subscales (Table 6). Results from the test-retest correlations were high, ranging from .85 to .92 , with a mean value of .88 , which are considered high and all were statistically significant.

Means of students' (sample 1, males and females, $N=1592)$ motivation in each subscale from highest to lowest, were: external regulation $(M=5.29$, $S D=1.19)$, identified regulation $(M=5.19, S D=1.19)$, IM-to know $(M=5.14, S D=1.16)$, introjected regulation $(M=4.59, S D=1.42)$, IM-accomplishment $(M=4.43, S D=1.28)$, IM-stimulation $(M=3.67$, $S D=1.28)$, and amotivation $(M=2.52, S D=1.41)$. Means and standard deviations for each subscale of motivation according to sex are presented in Table 7 . The analyses of variance revealed signifi- 
Table 3

Factor loadings from the confirmatory factor analysis

\begin{tabular}{|c|c|c|c|c|}
\hline Item & Loading & SE & $t$ statistic & $p$ \\
\hline Amotivation 5 & 1.10 & .04 & 27.97 & $<.001$ \\
\hline Amotivation 12 & 1.08 & .04 & 25.57 & $<.001$ \\
\hline Amotivation 19 & 1.21 & .03 & 35.72 & $<.001$ \\
\hline Amotivation 26 & 1.31 & .04 & 37.54 & $<.001$ \\
\hline External Regulation 1 & 0.83 & .05 & 18.12 & $<.001$ \\
\hline External Regulation 8 & 1.13 & .03 & 34.24 & $<.001$ \\
\hline External Regulation 15 & 1.06 & .03 & 33.11 & $<.001$ \\
\hline External Regulation 22 & 1.10 & .03 & 35.77 & $<.001$ \\
\hline Introjected Regulation 7 & 1.22 & .04 & 28.15 & $<.001$ \\
\hline Introjected Regulation 14 & 1.15 & .04 & 29.60 & $<.001$ \\
\hline Introjected Regulation 21 & 1.29 & .04 & 3.16 & $<.001$ \\
\hline Introjected Regulation 28 & 1.23 & .04 & 33.12 & $<.001$ \\
\hline Identified Regulation 3 & 0.90 & .04 & 25.32 & $<.001$ \\
\hline Identified Regulation 10 & 1.00 & .04 & 28.13 & $<.001$ \\
\hline Identified Regulation 17 & 0.94 & .03 & 28.86 & $<.001$ \\
\hline Identified Regulation 24 & 0.95 & .03 & 27.70 & $<.001$ \\
\hline IM - to Know 2 & 0.80 & .04 & 23.08 & $<.001$ \\
\hline IM - to Know 9 & 0.90 & .03 & 27.01 & $<.001$ \\
\hline IM - to Know 16 & 1.03 & .03 & 3.21 & $<.001$ \\
\hline IM - to Know 23 & 0.96 & .03 & 28.95 & $<.001$ \\
\hline IM - Accomplishment 6 & 1.04 & .04 & 27.93 & $<.001$ \\
\hline IM - Accomplishment 13 & 1.13 & .04 & 3.17 & $<.001$ \\
\hline IM - Accomplishment 20 & 1.06 & .04 & 28.99 & $<.001$ \\
\hline IM - Accomplishment 27 & 0.88 & .04 & 24.79 & $<.001$ \\
\hline IM - Stimulation 4 & 0.76 & .04 & 18.46 & $<.001$ \\
\hline IM - Stimulation 11 & 1.17 & .04 & 31.71 & $<.001$ \\
\hline IM - Stimulation 18 & 1.19 & .04 & 33.56 & $<.001$ \\
\hline IM - Stimulation 25 & 1.11 & .04 & 28.85 & $<.001$ \\
\hline
\end{tabular}

Note. IM - intrinsic motivation

cant differences in motivation between males and females. Significant sex differences were found for five subscales: amotivation, IM-to know and all subscales of extrinsic motivation. The results revealed that female students scored higher than males on external regulation, introjected regulation, identified regulation and IM-to know. Furthermore, female students scored lower than males on amotivation. However, the results indicated that there are no significant sex differences in IM-accomplishment and IM-stimulation.

\section{DISCUSSION}

The aim of the study was to provide and examine the validity of the Polish version of the AMS. This study also examined students' motivation according to the self-determination theory, with regard to gender differences. The AMS is a tool commonly used for assessing motivation in the education environment.

The AMS scale was originally created in French by Vallerand et al. (1989). After a few years, the AMS was translated into English and validated in Canada
Validity and reliability of the Polish version of the Academic Motivation Scale 
Table 4

Covariance between latent variables

\begin{tabular}{|c|c|c|c|c|}
\hline Latent variables & Covariance & SE & $t$ statistic & $p$ \\
\hline Amotivation - External Reg. & -.42 & .03 & -15.91 & $<.001$ \\
\hline Amotivation - Introjected Reg. & -.32 & .03 & -10.66 & $<.001$ \\
\hline Amotivation - Identified Reg. & -.53 & .03 & -20.78 & $<.001$ \\
\hline Amotivation - IM to Know & -.50 & .03 & -19.41 & $<.001$ \\
\hline Amotivation - IM Accomplishment & -.35 & .03 & -11.91 & $<.001$ \\
\hline Amotivation - IM Stimulation & -.26 & .03 & -8.40 & $<.001$ \\
\hline External Reg. - Introjected Reg. & .66 & .02 & 32.21 & $<.001$ \\
\hline External Reg. - Identified Reg. & .79 & .02 & 45.82 & $<.001$ \\
\hline External Reg. - IM to Know & .44 & .03 & 15.97 & $<.001$ \\
\hline External Reg. - IM Accomplishment & .45 & .03 & 16.47 & $<.001$ \\
\hline External Reg. - IM Stimulation & .31 & .03 & 10.37 & $<.001$ \\
\hline Introjected Reg. - Identified Reg. & .60 & .03 & 24.32 & $<.001$ \\
\hline Introjected Reg. - IM to Know & .55 & .03 & 21.05 & $<.001$ \\
\hline Introjected Reg. - IM Accomplishment & .78 & .02 & 44.23 & $<.001$ \\
\hline Introjected Reg. - IM Stimulation & .53 & .03 & 21.10 & $<.001$ \\
\hline Identified Reg. - IM to Know & .76 & .02 & 39.46 & $<.001$ \\
\hline Identified Reg. - IM Accomplishment & .62 & .03 & 24.91 & $<.001$ \\
\hline Identified Reg. - IM Stimulation & .59 & .03 & 23.06 & $<.001$ \\
\hline IM to Know - IM Accomplishment & .75 & .02 & 39.58 & $<.001$ \\
\hline IM to Know - IM Stimulation & .73 & .02 & 36.92 & $<.001$ \\
\hline IM Accomplishment - IM Stimulation & .73 & .02 & 37.96 & $<.001$ \\
\hline
\end{tabular}

Note. Reg. - regulation; IM - intrinsic motivation

(Vallerand et al., 1992). Later research supported the concurrent and construct validity of the English version of the AMS (Vallerand et al., 1993). Through the years, the AMS has been used in many studies for many different purposes, e.g. to examine students' motivation in education (Fortier, Vallerand, \& Guay, 1995); to study the impact of the sense of competence and identity on the motivation to study (Faye \& Sharpe, 2008); to analyse the correlation between personality traits (neuroticism, extroversion, openness, agreeableness and conscientiousness) and motivation to study (Komarraju et al., 2009); to study the mechanism of strengthening autonomy and motivation through the existence of supporting interpersonal relationships between students, their parents and teachers (Guay et al., 2013); or to confirm the existence of a motivation continuum (Litalien et al., 2017).

The AMS has been translated into many different languages: Greek (Barkoukis et al., 2008), Italian (Aliv- ernini \& Lucidi, 2008), Turkish (Karagüven, 2012), Spanish (Stover et al., 2012) German (Wilkesmann et al., 2012), Romanian (Maican \& Lixandroiu, 2015), Spanish (Orsini et al., 2015), Hungarian (Tóth-Király et al., 2017). However, the Polish version has never been appropriately adapted and validated. Although an attempt to adapt the Polish version of the AMS has been made, the sample size in that study was too small, models were not assessed and the seven-factor structure was not supported (Ardeńska et al., 2016).

The present study is based on the SDT construct of motivation. An exploratory factor analysis (EFA) confirmed three main types of motivation in the AMS: amotivation, extrinsic and intrinsic motivation. The Kaiser criterion was appropriately applied, the eigenvalues of four factors were greater than 1.00 and explained $58.86 \%$ of total variance. According to Cattell's scree plot five factors were "over the scree", the fifth factor eigenvalue was .95 and five factors explained $62.25 \%$ of total variance. Therefore, five mod- 
Table 5

Internal consistency values (Cronbach $\alpha)$, sample $1(N=1592)$

\begin{tabular}{|c|c|c|c|c|}
\hline \multirow[t]{2}{*}{ Item } & \multirow{2}{*}{$\begin{array}{c}\text { AMS } \\
\alpha=.87\end{array}$} & \multirow{2}{*}{$\begin{array}{c}\text { Amotivation } \alpha=.86 \\
\text { Motivation } \alpha=.93\end{array}$} & \multicolumn{2}{|c|}{ Subscales } \\
\hline & & & $\alpha$ & $\begin{array}{l}\text { Alpha after } \\
\text { removing the item }\end{array}$ \\
\hline Amotivation 5 & .88 & .83 & .86 & .83 \\
\hline Amotivation 12 & .88 & .85 & & .85 \\
\hline Amotivation 19 & .88 & .82 & & .82 \\
\hline Amotivation 26 & .88 & .80 & & .80 \\
\hline External Regulation 1 & .87 & .93 & .78 & .82 \\
\hline External Regulation 8 & .86 & .92 & & .68 \\
\hline External Regulation 15 & .86 & .92 & & .70 \\
\hline External Regulation 22 & .86 & .92 & & .69 \\
\hline Introjected Regulation 7 & .86 & .92 & .82 & .79 \\
\hline Introjected Regulation 14 & .86 & .92 & & .78 \\
\hline Introjected Regulation 21 & .86 & .92 & & .76 \\
\hline Introjected Regulation 28 & .86 & .92 & & .76 \\
\hline Identified Regulation 3 & .86 & .92 & .82 & .78 \\
\hline Identified Regulation 10 & .86 & .92 & & .77 \\
\hline Identified Regulation 17 & .86 & .92 & & .77 \\
\hline Identified Regulation 24 & .86 & .92 & & .79 \\
\hline IM - to Know 2 & .86 & .92 & .82 & .79 \\
\hline IM - to Know 9 & .86 & .92 & & .76 \\
\hline IM - to Know 16 & .86 & .92 & & .76 \\
\hline IM - to Know 23 & .86 & .92 & & .79 \\
\hline IM - Accomplishment 6 & .86 & .92 & .83 & .77 \\
\hline IM - Accomplishment 13 & .86 & .92 & & .77 \\
\hline IM - Accomplishment 20 & .86 & .92 & & .79 \\
\hline IM - Accomplishment 27 & .86 & .92 & & .79 \\
\hline IM - Stimulation 4 & .86 & .92 & .81 & .83 \\
\hline IM - Stimulation 11 & .86 & .92 & & .72 \\
\hline IM - Stimulation 18 & .86 & .92 & & .72 \\
\hline IM - Stimulation 25 & .86 & .92 & & .75 \\
\hline
\end{tabular}

Note. IM - intrinsic motivation

els were tested using a confirmatory factor analysis (CFA). In the Karagüven (2012) study, an EFA was used and distinguished only five factors with eigenvalues greater than 1.00 , accounting for $58.06 \%$ of the total variance. Wilkesmann et al. (2012) used only a principal component analysis instead of a CFA and found only four factors instead of the original seven factors.
In the present study, confirmatory factor analysis (CFA) supported the seven-factor and 28-item structure of the Polish version of the AMS. The 7-factor correlated Model 5 yielded satisfactory fit values and all factor loadings were statistically significant. Similarly, CFA confirmed the 7-factor model in the studies conducted by Vallerand et al. (1989, 1992), Cokley et al. (2001) and Barkoukis et al. (2008). Vallerand
Validity and reliability of the Polish version of the Academic Motivation Scale 
Table 6

Internal consistency values (Cronbach $\alpha)$ and test-retest correlations $(N=49)$

\begin{tabular}{|c|c|c|c|}
\hline \multirow[t]{2}{*}{ Subscales } & \multicolumn{2}{|c|}{$\alpha$} & \multirow{2}{*}{$\begin{array}{c}\text { Test-retest } \\
\text { correlations }\end{array}$} \\
\hline & Pretest & Posttest & \\
\hline Amotivation & .83 & .94 & .85 \\
\hline External Regulation & .73 & .80 & .87 \\
\hline Introjected Regulation & .84 & .92 & .92 \\
\hline Identified Regulation & .88 & .85 & .87 \\
\hline IM - to Know & .78 & .82 & .88 \\
\hline IM - Accomplishment & .82 & .87 & .90 \\
\hline IM - Stimulation & .86 & .90 & .89 \\
\hline
\end{tabular}

Note. IM - intrinsic motivation

Table 7

Means and standard deviations for males and females $(N=1592)$

\begin{tabular}{lcccccc}
\hline Subscales & \multicolumn{2}{c}{$\begin{array}{c}\text { Males } \\
(n=653)\end{array}$} & \multicolumn{2}{c}{$\begin{array}{c}\text { Females } \\
(n=939)\end{array}$} & \multicolumn{2}{c}{ ANOVA } \\
\cline { 2 - 7 } & $M$ & $S D$ & $M$ & $S D$ & $F$ & $p$ \\
\hline Amotivation & 2.70 & 1.42 & 2.40 & 1.40 & 17.14 & $<.001$ \\
External Regulation & 5.13 & 1.29 & 5.39 & 1.11 & 18.89 & $<.001$ \\
Introjected Regulation & 4.40 & 1.48 & 4.71 & 1.36 & 18.37 & $<.001$ \\
Identified Regulation & 4.97 & 1.26 & 5.34 & 1.10 & 37.81 & $<.001$ \\
IM - to Know & 5.01 & 1.22 & 5.24 & 1.11 & 15.34 & $<.001$ \\
IM - Accomplishment & 4.37 & 1.28 & 4.46 & 1.27 & 1.81 & .179 \\
IM - Stimulation & 3.65 & 1.27 & 3.68 & 1.30 & 0.26 & .609 \\
\hline Note. IM - intrinsic motivation & & & & & &
\end{tabular}

et al. (1989) reported fit values of $\chi^{2}=668.8, d f=323$, $p<.001$, GFI $=.930$, AGFI $=.921$ in the study of the original French version of the AMS, and fit values of $\chi^{2}=748.64, d f=303, p<.001$, GFI $=.94$, AGFI $=.91$ in the study of the original English version of the AMS (Vallerand et al., 1992). In the Cokley et al. (2001) study on the United States sample, the fit values were $\chi^{2}=709.155, p<.001, \chi^{2} / d f$ ratio $=2.1$, RMSEA $=.07$, SRMR $=.08$, CFI $=.90$, NFI $=.83$. In the Barkoukis et al. (2008) study, reported fit values were $\chi^{2}=1032.40, p<.001, d f=326, \chi^{2} / d f$ ratio $=3.16$, GFI $=.894$, AGFI $=.869$, RMSEA $=.057$, SRMR $=.059$. Karagüven (2012) examined the factorial structure of the 7-factor model in the original scale and obtained fit values of $\chi^{2}=1017.74, d f=329, p<.001$, $\chi^{2} / d f=3.094$, GFI $=.84$, AGFI $=.81$, RMSEA $=.73$, SRMR $=.65$

Cronbach's $\alpha$ was used to estimate reliability, with the expectation to reach values above 0.7 (Nunnally, 1978; Nunnally \& Bernstein, 1994). The results from this study revealed that Cronbach $\alpha$ values were high for the AMS, as well as for all the subscales. These findings were similar to those reported by Vallerand et al. (1992), Cokley et al. (2001), Fairchild et al. (2005), Barkoukis et al. (2008), and Karagüven (2012). In the Vallerand et al. (1992) study, $\alpha$ values ranged from .83 to .86 , with the exception of the identified regulation, which had an $\alpha$ of .62. In the Cokley et al. (2001) study, Cronbach $\alpha$ values ranged from .70 for identified regulation to .86 in the case of amotivation. Results from the Fairchild et al. (2005) study revealed values ranging from .77 (identified regulation) to .90 (IM-accomplishment). In the Ratelle, Guay, Vallerand, Larose, \& Senecal (2007) study on college students, Cronbach $\alpha$ values ranged from .75 (identified regulation) to .95 (all IM subscales). Alpha values reported in the Barkoukis et al. (2008) study were between .72 (identified regulation) and .79 (IM-to know), with the exception of IM-stimulation, which had an $\alpha$ value of .55. In the Karagüven (2012) study, the Cronbach $\alpha$ 
value was .67. Wilkesmann et al. (2012) distinguished four factors in the structure of the AMS and reported Cronbach $\alpha$ values of .85 for the 'intrinsic motivation' factor, .77 for 'identified motivation', .75 for 'extrinsic motivation', and .80 for 'amotivation'. Furthermore, in the present study, the $\alpha$ value for motivation was .93 after removing all items of the amotivation subscale. These results support internal consistency of the scale and subscales of the Polish version of the AMS.

The temporal reliability of the scale is supported by the high test-retest values. Alpha coefficients reached acceptable values, as they were consistently higher than .70 for all subscales. These results were in accord with the findings from the French AMS study by Vallerand et al. (1989), which revealed values ranging from .70 to .89 in pretest and from .82 to .93 in posttest, as well as their English AMS study (Vallerand et al., 1992), which showed values ranging from .72 to .91 in pretest and from .78 to .90 in posttest. Similarly, in the Barkoukis et al. (2008) study, reported values were higher than .70 in general.

Results from this study regarding the test-retest correlations were high ranging. These results were higher than those found in the French AMS study (Vallerand et al., 1989), which revealed values ranging from .69 to .81 , as well as the English AMS study (Vallerand et al., 1992), which showed values ranging from .71 to .83 .

The results of the study support the reliability, internal consistency and validity of the seven-factor model of the Polish version of the AMS.

The second aim of the present study was to examine motivation of students enrolled in physical education, tourism and recreation, physiotherapy, sport, or sport and tourism management. Motivation is especially important to students of those fields, because of the necessity to combine intellectual skills and physical fitness in order to succeed in higher education. Students of physical education, sport and other faculties of physical activity constitute a valuable social potential, because of the wellestablished awareness of the importance of human activity for people's well-being and public health. Physical activity and sport are also important in the prevention of health-threatening behaviours (Jochimek, Krokosz, \& Lipowski, 2017). University authorities should monitor students' motivation to study, and the AMS tool may prove useful for the assessment of different levels of motivation. The value of motivation is noted by many Polish researchers; e.g. the motivational function of goals in physical activity, recreation and sport is recognized by Lipowski \& Zaleski (2015), the authors of the Inventory of Physical Activity Objectives, a high reliability tool (Cronbach's $\alpha=.78$ ).

The present analysis of student motivation revealed significant gender differences regarding 5 subscales. Female students scored higher than males on external regulation, introjected regulation, identified regulation and IM-to know. The importance of intrinsic motivation should be particularly appreciated (Ryan, Vallerand, \& Deci, 1984). Similar findings were reported in Canadian (Vallerand et al., 1992), Greek (Barkoukis et al., 2008) and United States (Horyna \& Bonds-Raacke, 2012) samples. In the study carried out by Vallerand et al. (1992) females reported higher levels than males on 5 subscales (IM-knowledge, IM-accomplishment, IM-stimulation, identified regulation, introjected regulation). Results from the Barkoukis et al. (2008) study revealed that females scored higher on IM-to know, and in the study conducted by Horyna \& Bonds-Raacke (2012), females scored higher than males on external regulation and identified regulation.

Furthermore, results from this study revealed that female students scored lower on amotivation than males. Similar findings were also obtained in previous studies conducted in Greece (Barkoukis et al., 2008), the United States (Horyna \& Bonds-Raacke, 2012) and Turkey (Turkmen, 2013). On the other hand, in the Wilkesmann et al. (2012) study, female students scored lower on extrinsic motivation than males, while Cokley et al. (2001) found no significant gender differences in motivation.

\section{CONCLUSIONS}

The findings from this study support the seven-factor structure of the Polish version of the Academic Motivation Scale (AMS) which was proposed by Vallerand et al. $(1989,1992)$. The fit indices in the confirmatory factor analysis (CFA) were satisfactory and all factor loadings were statistically significant for the 7-factor scale. The Cronbach $\alpha$ coefficients obtained from this study were high for all the subscales, confirming the high internal consistency and reliability of the scale. Furthermore, the test-retest values support reliability and temporal stability of the Polish AMS.

The results reveal significant differences between males and females regarding motivation. Female students showed higher levels in self-determined types of motivation as well as a lower level in amotivation than male students.

In conclusion, because of the evidence of high reliability and validity of the Polish version of the AMS, it can be considered a suitable instrument for determining different types of motivation of Polish university students. The Polish AMS may be useful to teachers and researchers, not only as a measure of student motivation but also to identify complex motivational problems. Furthermore, the findings of the AMS may be valuable to administrators and politicians who reform the educational system, which should always promote a more self-determined approach to learning.
Validity and reliability of the Polish version of the Academic Motivation Scale 


\section{REFERENCES}

Alivernini, F., \& Lucidi, F. (2008). The Academic Motivation Scale (AMS): Factorial structure, invariance and validity in the Italian context. Testing, Psychometrics, Methodology in Applied Psychology, 15, 211-220. https://doi.org/10.4473/TPM.15.4.3

Ardeńska, A., Tomik, R., Berber, S., Düz, B., Çivak, B., Çalişkan, U., \& Ogrodnik, J. (2016). A comparison of physical education' students' motivation us-
Magdalena Ardeńska, Agnieszka Ardeńska, Rajmund Tomik ing Polish and Turkish versions of the Academic Motivation Scale. Journal of Human Kinetics, 54, 207-218. https://doi.org/10.1515/hukin-20160046

Barkoukis, V., Tsorbatzoudis, H., Grouios, G., \& Sideridis, G. (2008). The assessment of intrinsic and extrinsic motivation and amotivation: Validity and reliability of the Greek version of the Academic Motivation Scale. Assessment in Education: Principles, Policy \& Practice, 15, 39-55. https://doi. org/10.1080/09695940701876128

Boone, H. N., \& Boone, D. A. (2012). Analyzing Likert Data. The Journal of Extension, 50, 1-5.

Cattell, R. B. (1966). The scree test for the number of factors. Multivariate Behavioral Research, 1, 245276. https://doi.org/10.1207/s15327906mbr0102_10

Cattell, R. B. (1971). Abilities: Their structure, growth and action. Boston: Houghton Mifflin.

Cokley, K., Bernard, N., Cunningham, D., \& Motoike, J. (2001). A psychometric investigation of the Academic Motivation Scale using a United States sample. Measurement and Evaluation in Counseling and Development, 34, 109-119.

Costa, P. T., \& McCrae, R. R. (1992). Four ways five factors are basic. Personality and Individual Differences, 13, 653-665. https://doi.org/10.1016/01918869(92)90236-I

Csikszentmihalyi, M. (1990). Flow: The Psychology of Optimal Experience. New York: Harper \& Row.

Deci, E. L. (1971). Effects of externally mediated rewards of intrinsic motivation. Journal of Personality and Social Psychology, 18, 105-115. https://doi. org/10.1037/h0030644

Deci, E. L. (1972). Intrinsic motivation, extrinsic reinforcement, and inequity. Journal of Personality and Social Psychology, 22, 113-120. https://doi. org/10.1037/h0032355

Deci, E. L. (1975). Intrinsic motivation. New York: Plenum Press.

Deci, E. L., Eghrari, H., Patrick, B. C., \& Leone, D. R. (1994). Facilitating: The self-determination theory perspective. Journal of Personality, 62, 119-142. https://doi.org/10.1111/j.1467-6494.1994.tb00797.x

Deci, E. L., Koestner, R., \& Ryan, R. M. (1999). A metaanalytic review of experiments examining the effects of extrinsic rewards on intrinsic motivation. Psychological Bulletin, 125, 627-668. https://doi. org/10.1037//0033-2909.125.6.627
Deci, E. L., \& Ryan, R. M. (1985). Intrinsic Motivation and Self-Determination in Human Behavior. New York: Plenum Press.

Deci, E. L., \& Ryan, R. M. (1990). A motivational approach to self: Integration in personality. In R. A. Dienstbier (Ed.), Current theory and research in motivation, Vol. 38. Nebraska Symposium on Motivation, 1990: Perspectives on motivation (pp. 237288). Lincoln, NE: University of Nebraska Press.

Deci, E. L., \& Ryan, R. M. (2000). The "what" and "why" of goal pursuits: Human needs and the self-determination of behavior. Psychological Inquiry, 11, 227268. https://doi.org/10.1207/s15327965pli1104_01

Deci, E. L., \& Ryan, R. M. (2008). Self-determination theory: A macrotheory of human motivation, development, and health. Canadian Psychology, 49, 182-185. https://doi.org/10.1037/a0012801

Deci, E. L., Vallerand, R. J., Pelletier, L. G., \& Ryan, R. M. (1991). Motivation and education: The self-determination perspective. Educational Psychologist, 26, 325346. https://doi.org/10.1207/s15326985ep2603\&4_6

Eysenck, H. (1991). Dimensions of personality: 16, 5 or 3? Criteria of taxonomic paradigm. Personality and Individual Differences, 12, 773-790. https://doi. org/10.1016/0191-8869(91)90144-z

Eysenck, H. J. (1992). Four ways five factors are not basic. Personality and Individual Differences, 13, 667673. https://doi.org/10.1016/0191-8869(92)90237-j

Fairchild, A. J., Horst, S. J., Finney, S. J., \& Barron, K. E. (2005). Evaluating existing and new validity evidence for the Academic Motivation Scale. Contemporary Educational Psychology, 30, 331-358. https://doi.org/10.1016/j.cedpsych.2004.11.001

Faye, C., \& Sharpe, D. (2008). Academic motivation in university: The role of basic psychological needs and identity formation. Canadian Journal of Behavioural Science, 40, 189-199. https://doi. org/10.1037/a0012858

Fortier, M. S., Vallerand, R. J., \& Guay, F. (1995). Academic motivation and school performance: Toward a structural model. Contemporary Educational Psychology, 2, 257-274. https://doi.org/10.1006/ ceps.1995.1017

Guay, F., Ratelle, C., Larose, S., Vallerand, R. J., \& Vitoro, F. (2013). The number of autonomy-supportive relationships: Are more relationships better for motivation, perceived competence, and achievement? Contemporary Educational Psychology, 38, 375-382. https://doi.org/10.1016/j.cedpsych.2013.07.005

Hornowska, E. (2018). Testy psychologiczne. Teoria i praktyka. Wykłady z psychologii, tom 6 [Psychological tests. Theory and practice. Lectures on psychology, volume 6]. Warszawa: Wydawnictwo Naukowe Scholar.

Hornowska, E., \& Paluchowski, W. J. (2011). Kulturowa adaptacja testów psychologicznych [Cultural adaptation of psychological tests]. In J. M. Brzeziński (Ed.), Metodologia badań spotecznych. Wybór 
tekstów [Methodology of social research. Selection of texts] (pp. 177-242). Poznań: Wydawnictwo Zysk i S-ka.

Horyna, B., \& Bonds-Raacke, J. M. (2012). Differences in students' motivation to attend college: Large versus small high schools. Education, 132, 708-724.

Jochimek, M., Krokosz, D., \& Lipowski, M. (2017). Physical activity and sport as a protective factor against health-threatening experiments with adulthood. Baltic Journal of Health and Physical Activity, 9, 112-124. https://doi.org/10.29359/bjhpa.09.4.09

Karagüven, H. Ü. M. (2012). The adaptation of Academic Motivation Scale to Turkish. Educational Sciences: Theory \& Practice, 12, 2611-2618.

Komarraju, M., Karau, S. J., \& Schmeck, R. R. (2009). Role of the Big Five personality traits in predicting college students' academic motivation and achievement. Learning and Individual Differences, 19, 47-52. https://doi.org/10.1016/j.lindif.2008.07.001

Likert, R. (1932). A technique for the measurement of attitudes. Archives of Psychology, 140, 1-55.

Lipowski, M., \& Zaleski, Z. (2015). Inventory of Physical Activity Objectives: a new method of measuring motives for physical activity and sport. Health Psychology Report, 3, 47-58. https://doi.org/10.5114/ hpr.2015.49462

Litalien, D., Morin, A. J. S., Gagné, M., Vallerand, R. J., Losier, G. F., \& Ryan, R. M. (2017). Evidence of a continuum structure of academic self-determination: A two-study test using a bifactor-ESEM representation of academic motivation. Contemporary Educational Psychology, 51, 67-82. https:// doi.org/10.1016/j.cedpsych.2017.06.010

Maican, C., \& Lixandroiu, R. (2015). Academic Motivation for Business Information Systems students. Risk in Contemporary Economy, 60-64.

Nunnally, J. (1978). Psychometric theory. New York: McGraw-Hill.

Nunnally, J. C., \& Bernstein, I. H. (1994). Psychometric theory. New York: McGraw-Hill.

Orsini, C., Binnie, V., Evans, P., Ledezma, P., Fuentes, F., \& Villegas, M. J. (2015). Psychometric validation of the Academic Motivation Scale in a dental student sample. Journal of Dental Education, 79, 971-981.

Ratelle, C. F., Guay, F., Vallerand, R. J., Larose, S., \& Senecal, C. (2007). Autonomous, controlled, and amotivated types of academic motivation: A person-oriented analysis. Journal of Educational Psychology, 99, 734-746. https://doi.org/10.1037/00220663.99.4.734

Ryan, R. M. (1995). Psychological needs and the facilitation of integrative processes. Journal of Personality, 63, 397-427. https://doi.org/10.1111/j.1467-6494.1995. tb00501.x

Ryan, R. M., \& Deci, E. L. (2000a). Intrinsic and extrinsic motivations: Classic definitions and new directions. Contemporary Educational Psychology, 25, 54-67. https://doi.org/10.1006/ceps. 1999.1020
Ryan, R. M., \& Deci, E. L. (2000b). Self-determination theory and the facilitation of intrinsic motivation, social development and well-being. American Psychologist, 55, 68-78. https://doi.org/10.1037//0003066x.55.1.68

Ryan, R. M., Koestner, R., \& Deci, E. L. (1991). Egoinvolved persistence: When free choice behavior is not intrinsically motivated. Motivation and Emotion, 15, 185-205. https://doi.org/10.1007/bf00995170

Ryan, R. M., Soenens, B., Vansteenkiste, M., \& Deci, E. L. (2019). Reflections on self-determination theory as an organizing framework for personality psychology: Interfaces, integrations, issues, and unfinished business. Journal of Personality, 87, 115-145. https:// doi.org/10.1111/jopy. 12440

Ryan, R. M., Vallerand, R. J., \& Deci, E. L. (1984). Intrinsic motivation in sport: A cognitive evaluation theory interpretation. In W. F. Straub \& J. M. Williams (Eds.), Cognitive sport psychology (pp. 231242). Lancing, NY: Sport Science Associates.

Ryan, R. M., Williams, G. C., Patrick, H., \& Deci, E. L. (2009). Self-determination theory and physical activity: The dynamics of motivation in development and wellness. Hellenic Journal of Psychology, 6, 107-124.

Sagan, A. (2003a). Model pomiarowy satysfakcji i lojalności [Measurement model of satisfaction and loyalty]. StatSoft Polska, 75-85.

Sagan, A. (2003b). Model strukturalny relacji między satysfakcją i lojalnością wobec marki [The structural model of the relationship between satisfaction and loyalty to the brand]. StatSoft Polska, 87-92.

Stover, J. B., de la Iglesia, G., Boubeta, A. R., \& Liporace, M. F. (2012). Academic Motivation Scale: adaptation and psychometric analyses for high school and college students. Psychology Research and Behavior Management, 5, 71-83. https://doi. org/10.2147/prbm.s33188

Suhr, D. (2006). Exploratory or Confirmatory Factor Analysis. SAS Users Group International Conference (pp. 1-17). Cary: SAS Institute, Inc.

Tóth-Király, I., Orosz, G., Dombi, E., Jagodics, B., Farkas, D., \& Amoura, C. (2017). Cross-cultural comparative examination of the Academic Motivation Scale using exploratory structural equation modeling. Personality and Individual Differences, 106, 130-135. https://doi.org/10.1016/j.paid.2016.10.048

Turkmen, M. (2013). The relationships between gender, physical self-perception, sport experience, motivation orientations and academic success. International Journal of Academic Research, 5, 66-72. https://doi.org/10.7813/2075-4124.2013/5-5/b.10

Vallerand, R. J. (2000). Deci and Ryan's self-determination theory: A view from the hierarchical model of intrinsic and extrinsic motivation. Psychological Inquiry, 11, 312-318. https://doi.org/10.1207/ S15327965PLI1104_02

Vallerand, R. J., Blais, M. R., Brière, N. M., \& Pelletier, L. G. (1989). Construction et validation de
Validity and reliability of the Polish version of the Academic Motivation Scale 
Magdalena

Ardeńska,

Agnieszka

Ardeńska,

Rajmund Tomik l'échelle de motivation en éducation (EME) [Construction and validation of the Motivation toward Education Scale]. Canadian Journal of Behavioural Science / Revue canadienne des sciences du comportement, 21, 323-349. https://doi.org/10.1037/ h0079855

Vallerand, R. J., \& Lalande, D. (2011). The MPIC model: The perspective of the Hierarchical Model of Intrinsic and Extrinsic Motivation. Psychological Inquiry, 22, 45-51. https://doi.org/10.1080/104784 0x.2011.545366

Vallerand, R. J., Pelletier, L. G., Blais, M. R., Brière, N. M., Senecal, C., \& Vallieres, E. F. (1992). The Academic Motivation Scale: A measure of intrinsic, extrinsic, and amotivation in education. Educational and Psychological Measurement, 52, 1003-1017. https://doi. org/10.1177/0013164492052004025

Vallerand, R. J., Pelletier, L. G., Blais, M. R., Brière, N. M., Senecal, C., \& Vallieres, E. F. (1993). On the assessment of intrinsic, extrinsic, and amotivation in education: Evidence on the concurrent and construct validity of the Academic Motivation Scale. Educational and Psychological Measurement, 53, 159-172. https://doi.org/10.1177/0013164493053001018

Vallerand, R. J., Pelletier, L. G., \& Koestner, R. (2008). Reflections on self-determination theory. Canadian Psychology, 49, 257-262. https://doi.org/10.1037/ a0012804

Wilkesmann, U., Fischer, H., \& Virgillito, A. (2012). Academic motivation of students - the German case. Discussion Papers des Zentrums für HochschulBildung, Technische Universität Dortmund, 2, 1-19. 